\title{
Update on Vitamin E and Its Potential Role in Preventing or Treating Bronchopulmonary Dysplasia
}

\author{
Cosby A. Stone Jr. ${ }^{a}$ Cindy T. McEvoy ${ }^{f} \quad$ Judy L. Aschner ${ }^{\mathrm{e}} \quad$ Ashudee Kirk $^{\mathrm{a}}$ \\ Christian Rosas-Salazarb Joan M. Cook-Mills $^{d}$ Paul E. Moore $^{b}$ \\ William F. Walsh ${ }^{c}$ Tina V. Hartert ${ }^{a}$ \\ ${ }^{a}$ Division of Allergy, Pulmonary and Critical Care Medicine, Department of Medicine, Vanderbilt University Medical \\ Center, Nashville, TN, USA; ${ }^{b}$ Division of Allergy, Immunology and Pulmonary Medicine, Department of Pediatrics, \\ Vanderbilt University Medical Center, Nashville, TN, USA; ' $D i v i s i o n$ of Neonatology, Department of Pediatrics, \\ Vanderbilt University Medical Center, Nashville, TN, USA; ${ }^{d}$ Division of Allergy-Immunology, Department of

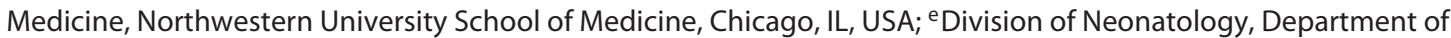 \\ Pediatrics, Albert Einstein College of Medicine and the Children's Hospital at Montefiore, Bronx, NY, USA; ${ }^{\mathrm{f} D i v i s i o n}$ \\ of Neonatology, Department of Pediatrics, Oregon Health and Science University, Portland, OR, USA
}

\section{Keywords}

Bronchopulmonary dysplasia - Chronic lung disease of prematurity - Vitamin E · a-Tocopherol · $\mathrm{y}$-Tocopherol ·

Tocopherol $\cdot$ Oxidative stress

\begin{abstract}
Vitamin $\mathrm{E}$ is obtained only through the diet and has a number of important biological activities, including functioning as an antioxidant. Evidence that free radicals may contribute to pathological processes such as bronchopulmonary dysplasia (BPD), a disease of prematurity associated with increased lung injury, inflammation and oxidative stress, led to trials of the antioxidant vitamin $\mathrm{E}$ (a-tocopherol) to prevent BPD with variable results. These trials were all conducted at supraphysiologic doses and 2 of these trials utilized a formulation containing a potentially harmful excipient. Since 1991, when the last of these trials was conducted, both neonatal
\end{abstract}

management strategies for minimizing oxygen and ventilator-related lung injury and our understanding of vitamin $\mathrm{E}$ isoforms in respiratory health have advanced substantially. It is now known that there are differences between the effects of vitamin $E$ isoforms a-tocopherol and $\gamma$-tocopherol on the development of respiratory morbidity and inflammation. What is not known is whether improvements in physiologic concentrations of individual or combinations of vitamin E isoforms during pregnancy or following preterm birth might prevent or reduce BPD development. The answers to these questions require adequately powered studies targeting pregnant women at risk of preterm birth or their premature infants immediately following birth, especially in certain subgroups that are at increased risk of vitamin E deficiency (e.g., smokers). The objective of this review is to compile, update, and interpret what is known about vitamin $\mathrm{E}$ isoforms and BPD since these first studies were conducted, and suggest future research directions.

(c) 2018 S. Karger AG, Basel

\section{KARGER}

(c) 2018 S. Karger AG, Basel 


\section{Introduction}

Bronchopulmonary dysplasia (BPD) is a form of chronic lung disease associated with premature birth, most commonly seen among extremely preterm infants (prior to 28 weeks of gestation) requiring treatment for respiratory distress syndrome (RDS). The USA has the highest rate of preterm birth among high-income countries [1]. Advances in neonatal care have improved the survival of extremely preterm infants who are at the highest risk of developing BPD. In spite of major advances in the treatment of RDS, the incidence of BPD has not changed over the last several decades. Substantial evidence suggests that oxidative stress likely plays an important role in the development of certain phenotypes of BPD [2]. Understanding the mechanisms underlying the role of oxidative stress as a risk factor for BPD or in the pathogenesis of BPD is of substantial interest, as interventions that safely prevent or ameliorate oxidative stress might serve as prevention strategies for this disease.

One such potential intervention is vitamin $\mathrm{E}$, which is known to neutralize free radicals and reduce oxidative stress. Vitamin E is also well tolerated as an oral supplement throughout pregnancy and infancy, and is routinely present in total parenteral nutrition (TPN) for premature infants, making it an attractive option for BPD prevention or treatment. This review will focus on outlining the association between oxidative stress, vitamin E, and BPD pathophysiology. We will then review new developments in understanding of individual vitamin $\mathrm{E}$ isoforms since the initial vitamin $\mathrm{E}$ trials were conducted in $\mathrm{BPD}$. Finally, we will discuss knowledge gaps that should be the focus of future research.

\section{Bronchopulmonary Dysplasia}

The most commonly applied definition of BPD is a requirement for oxygen at 36 weeks of corrected gestational age, although the physiologic usefulness of this definition has been questioned [3] and is being actively studied $[4,5]$. BPD was once thought to be a natural progression of RDS and therefore ameliorable by surfactant administration; however, the incidence of BPD has not decreased since surfactant became widely available [6]. Despite a multifactorial approach involving antenatal steroid therapy, early administration of surfactant, careful oxygen saturation targeting, avoidance of volutrauma and atelectasis, and an emphasis on intubation avoidance and early extubation, the incidence of BPD has remained stable [3, 7-13]. Demographically and pathologically, however, BPD is substantially different now $[12,14-16]$. In the current era, many infants diagnosed with BPD at 36 weeks gestational age have minimal respiratory distress at birth $[6,17]$, and the new clinical and histological picture of BPD is conceived as a failure or arrest of normal alveolar and lung vascular formation in the setting of extreme prematurity, uncommon in infants greater than $1,200 \mathrm{~g}$ and greater than 30 weeks gestation $[18,19]$. In addition, it is increasingly recognized that there are different phenotypes of BPD with variable contributions of oxidative stress, lung injury, lung repair, genetic predisposition, and epigenetic influences, among other factors [3].

\section{BPD and Oxidative Stress}

Oxidative stress results from the disrupted balance between the generation of free radicals (such as reactive oxygen species) and their removal by free radical scavenging systems [20]. Reactive oxygen species exist, therefore, in a delicate balance in the human body. They are generated by multiple enzyme systems and act as intermediates of normal cellular metabolism [21], performing essential roles as second messengers [22], in induction of cell death and apoptosis [23], and as local mediators of infection control and inflammation [24].

Multiple investigators have noted that in the first few days of life there is a difference in oxidation of lipids and proteins in preterm infants who develop BPD compared to full-term infants and adults [14], and compared to preterm infants who do not develop BPD [2]. These differences manifest as increased presence of free iron, transferrin, ferritin and lactoferrin in bronchoalveolar secretions, which in the presence of oxygen become free radicals [25-28]. In settings of local increases of reactive oxygen species, the imbalance triggers downstream damage to the neonatal lung, possibly via nitric oxide-dependent pathways of lung development $[29,30]$ or another downstream pathway that causes activation of the immune system and local inflammatory destruction of lung architecture. Thus, multiple studies suggest a role for free radical generation and lipid peroxidation in the presence of inhaled oxygen either causing or being a biomarker for BPD development [25-28].

Interventions that mitigate or control oxidative stress might therefore prevent the development of BPD in atrisk infants. Vitamin $\mathrm{E}$ is a potent antioxidant, known to 


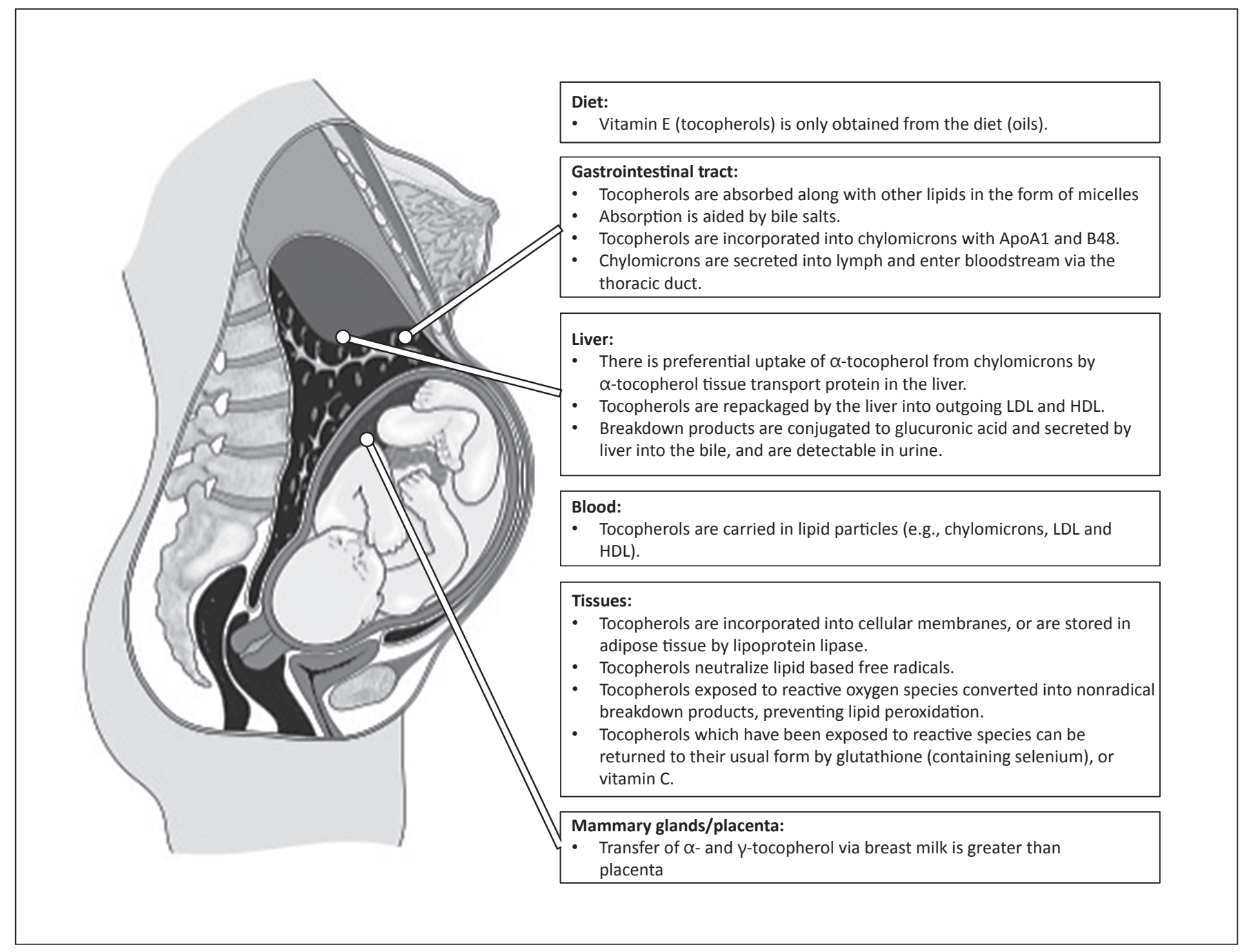

Fig. 1. Metabolism of vitamin E isoforms $\alpha$ - and $\gamma$-tocopherol during pregnancy. Tocopherols are found only in the diet and are transported via lipid pathways. The main site of tocopherol action is in tissues, where they are incorporated into cellular membranes

be essential for human health, and its easy tolerability as a normal part of the diet represents a feasible and acceptable potential antioxidant intervention. In 2015, Miller et al. [31] concluded that increasing first trimester maternal plasma a-tocopherol is associated with differential neonatal airway epithelial cell inflammatory mediator release, especially a decrease in tumor necrosis factor- $\alpha$ production, suggesting that $\alpha$-tocopherol may be an important local anti-inflammatory factor in the neonatal lung. Hereafter, we will review what is known about vita$\min \mathrm{E}$, its isoforms, and their potential role/association in the development of BPD. and act to stabilize lipids and prevent lipid peroxidation by free radicals. The illustration was modified from a public image (image modified with licensed permission; artist: Blamb; source: www. shutterstock.com).

\section{The Role of Vitamin E and Its Isoforms}

Vitamin $\mathrm{E}$ is one of the essential fat-soluble vitamins, but it is not synthesized by the human body and requires intake from food sources, typically oils (Fig. 1). There are 8 isoforms of vitamin E, known as $\alpha-, \beta-, \gamma^{-}$, and $\delta$ tocopherol and $\alpha-, \beta-, \gamma^{-}$, and $\delta$-tocotrienol [32]. The 2 best-studied isoforms of vitamin $\mathrm{E}$ are $\alpha$-tocopherol and $\gamma$-tocopherol. Dietary consumption of each isoform varies by food source [33]. At present, many foods and the majority of neonatal formulas in the USA deliver much greater $\gamma$-tocopherol than $\alpha$-tocopherol [34]. The func- 
Table 1. Comparing the effects of $\alpha$ - and $\gamma$-tocopherol isoforms of vitamin $E$ on lung growth and lung inflammation

\begin{tabular}{|c|c|c|}
\hline Effect & a-Tocopherol & $\gamma$-Tocopherol \\
\hline Infant $\mathrm{FEV}_{1}$ and $\mathrm{FVC}[54]$ & $\begin{array}{l}\text { Increased infant } \alpha \text {-tocopherol associated } \\
\text { with increases in } \mathrm{FEV}_{1} \text { and FVC }\end{array}$ & $\begin{array}{l}\text { Increased } \gamma \text {-tocopherol associated with } \\
\text { decreases in } \mathrm{FEV}_{1} \text { and FVC }\end{array}$ \\
\hline Effect on lipid peroxidation $[69,95]$ & $\begin{array}{l}\text { Associated with greater reductions in } \\
\text { lipid peroxidation }\end{array}$ & $\begin{array}{l}\text { Associated with lesser reductions in lipid } \\
\text { peroxidation }\end{array}$ \\
\hline Effect on IL-2 production $[96,97]$ & $\begin{array}{l}\text { Increased production by stimulated } \\
\text { peripheral blood mononuclear cells }\end{array}$ & Unknown \\
\hline $\begin{array}{l}\text { Effect on cyclooxygenase enzymes } \\
{[96,98-100]}\end{array}$ & Decreased prostaglandin $\mathrm{E}_{2}$ synthesis & Decreased prostaglandin $\mathrm{E}_{2}$ synthesis \\
\hline $\begin{array}{l}\text { Effect on intracellular pathways } \\
{[97,101-104]}\end{array}$ & $\begin{array}{l}\text { Inhibition of protein kinase B and C, } \\
\text { reduced nuclear factor kappa B }\end{array}$ & $\begin{array}{l}\text { Inhibition of protein kinase } B \text {, with mixed } \\
\text { inhibition/activation of protein kinase } C\end{array}$ \\
\hline $\begin{array}{l}\text { Effect on leukocyte trafficking/adhesion } \\
{[53,105,106]}\end{array}$ & Decreased expression of VCAM-1 & Increased expression of VCAM-1 \\
\hline $\begin{array}{l}\text { Effect on prevalent type I inflammation } \\
{[43,44,46-50,98,107,108]}\end{array}$ & Decreases neutrophilic inflammation & $\begin{array}{l}\text { Decreases neutrophilic inflammation } \\
\text { more than } \alpha \text {-tocopherol, reduced tumor } \\
\text { necrosis factor- } \alpha\end{array}$ \\
\hline $\begin{array}{l}\text { Effect on prevalent type II inflammation } \\
{[43,44,46-50,98]}\end{array}$ & $\begin{array}{l}\text { Decreases recruitment of dendritic cells } \\
\text { and eosinophils }\end{array}$ & $\begin{array}{l}\text { Increases recruitment of dendritic cells } \\
\text { and eosinophils in some models } \\
\text { Decreases eosinophil and basophil } \\
\text { recruitment in other models } \\
\text { Reductions in leukotriene } B_{4}\end{array}$ \\
\hline
\end{tabular}

tions of each isoform in the human body, while not fully described, appear to be different, some with anti-inflammatory and some with proinflammatory properties [35]. Human tissues preferentially retain $\alpha$-tocopherol and metabolize the other forms at higher rates $[36,37]$. The main carrier vehicle for tocopherols in the body are lipid particles (chylomicrons, LDL and HDL) [38]. Increased lipids can elevate measured plasma tocopherols, and decreased lipids can lower measured plasma tocopherols [39]. Premature infants on TPN can have elevations in measured cholesterol compared to infants on enteral breastmilk [40]. Simultaneous measurement of tocopherols and lipids is currently recommended for scientific investigations, and is important to identify measurements of plasma tocopherols that have been altered by extremes of lipid status [39, 41].

Both $\alpha$-tocopherol and $\gamma$-tocopherol have been called anti-inflammatory, but their downstream effects appear to be different, as outlined in Table 1. a-Tocopherol has been more extensively studied, as has its documented an- ti-inflammatory profile [42]. $\gamma$-Tocopherol also has antiinflammatory effects [42], especially in animal models and subjects with neutrophilic inflammation [43-51]. However, $\gamma$-tocopherol has also been reported to promote type II inflammation in the lungs and in other organs $[33,52,53]$. In human subjects with asthma, increased serum concentrations are associated with lower forced expiratory volume in $1 \mathrm{~s}\left(\mathrm{FEV}_{1}\right)$ [54]. Supplementation of primarily $\gamma$-tocopherol was shown to reduce plasma and urine concentrations of $\alpha$-tocopherol via undefined competitive mechanisms [55]. Subsequently, $\alpha$ and $\gamma$-tocopherol were noted by Marchese et al. [54] to have different primary roles in lung inflammation, with the isomers appearing to antagonize each other's metabolism. In human studies, higher $\alpha$-tocopherol is associated with a significantly decreased risk of asthma development, but the relationship of $\gamma$-tocopherol with asthma development is unclear [56]. 
Fig. 2. Beneficial and adverse effects of a-tocopherol on pregnancy, perinatal and early childhood outcomes, with strength of evidence: low birth weight $[57,94]$; preeclampsia [95-99]; intrauterine growth restriction [57, 94]; intraventricular hemorrhage [78]; retinopathy of prematurity [74, 77, 78, 100-104, 109]; BPD anemia [105]; sepsis [78]; intracranial hemorrhage [78]; asthma [54, 56, 106-108]; viral infection [110-114].
Low birth weight

- Preeclampsia

- Intrauterine growth restriction
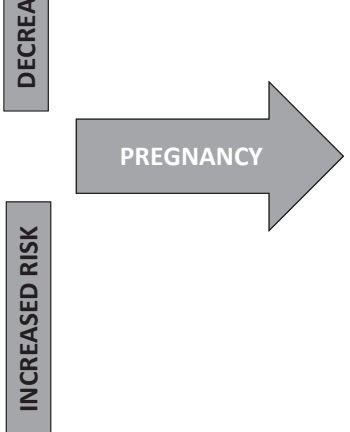

- Intraventricular hemorrhage

- Retinopathy of prematurity

- Bronchopulmonary dysplasia

- Anemia

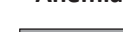

PERINATAL

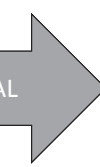

- Sepsis (with high dose, IV formulation)

- Intracranial hemorrhage (with high dose, IV formulation)
- Asthma

- Severe viral infection

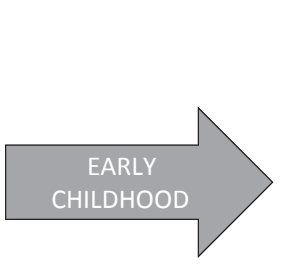

Strong evidence

Weaker/inconsistent evidence

\section{Vitamin E and Fetal Lung Development}

Maternal prenatal factors including nutrition play a vital role in fetal and infant lung growth, and the normal development of the lungs may be interrupted by preterm birth. Amongst other nutrients, maternal $\alpha$-tocopherol intake during pregnancy has been shown to be an important growth factor for fetal respiratory system development and other outcomes (Fig. 2) [57]. Murine models of BPD show accelerated growth in hypoplastic lung, increased lung complexity, and increased air surface with maternal supplementation of vitamin E containing $\alpha$-tocopherol and $\gamma$-tocopherol $[58,59]$.

\section{Vitamin E Concentrations in Prematurity}

In 1988, Falciglia et al. [60-62] noted that premature infants born at less than 33 weeks gestational age with RDS who went on to develop BPD had lower total plasma vitamin $\mathrm{E}$ at 3 days of life $(0.58 \pm 0.43 \mathrm{mg} / \mathrm{dL})$ compared to those with RDS who recovered without the development of BPD $(1.29 \pm 0.54 \mathrm{mg} / \mathrm{dL}, p<0.05)$. Decreased cord blood $\alpha$-tocopherol and selenium concentrations in premature infants less than 30 weeks gestation who were on a standardized respiratory and ventilatory protocol for RDS were subsequently found to predict increased risk of developing BPD [61]. Haga et al. [63] reported that even healthy, term infants appear to have a lower transport capacity for vitamin $\mathrm{E}$ compared with adults, resulting in lower plasma concentrations in cord blood samples compared to maternal plasma concentrations at delivery. Initial plasma concentrations of vitamin $\mathrm{E}$ in infancy have been shown to be associated with maternal concentrations prior to birth [64-66]. Placental transfer of tocopherol isoforms to the infant is limited due to maternal metabolism of excess tocopherols compared to postnatal breastfeeding [64-66]. Preterm infants who are not receiving breastmilk may also have lower measured $\alpha$-tocopherol concentrations after birth. Breastfeeding typically provides a higher $\alpha$-tocopherol content in colostrum and transitional milk compared with formula and TPN $[67,68]$.

$\mathrm{Wu}$ and Chou [65] measured $\alpha$ - and $\gamma$-tocopherol isoforms and lipid concentrations from venous blood in term infants of 38-42 weeks gestation and preterm infants of 28-34 weeks gestation to establish a comparison between the 2 infant groups. The 28- to 34-week-gestation infants had significantly lower serum mean $\alpha$-tocopherol concentrations compared to the older infants, but they had similar ratios of overall vitamin $\mathrm{E}$ to total lipids. There was a statistically significant correlation between neonatal and maternal vitamin $\mathrm{E}$ to total lipids ratios [65]. Better understanding of the effects of postnatal supplementation with various tocopherol isoforms will be crucial, because at the present time dietary supplementation of vitamin $E$ in neonatal care may be predominantly $\gamma$-and $\delta$-tocopherol based, as is also the case with prenatal vitamins [69]. 


\section{Vitamin E Supplementation and the Development of BPD}

Vitamin E has been extensively studied as an essential nutrient for the growth and development of infants, especially in its role as a potent antioxidant. It was hypothesized to be important in decreasing lung damage caused by the toxic effects of oxidant stress and oxygen toxicity [70]. Early studies, such as those by Ehrenkranz et al. [70, 71], measured infant vitamin E concentrations following birth and demonstrated a protective effect of higher vitamin E concentrations on pressure-related lung injury. These early observational studies did not account for the interaction (and likely opposing effects) of the vitamin $\mathrm{E}$ isoforms $\alpha$ - and $\gamma$-tocopherol on airway inflammation and lung disease risk that have subsequently been demonstrated $[33,54,72]$.

Investigators hypothesized that $a$-tocopherol supplementation might prevent either the oxidative lung injury or altered lung growth seen in preterm infants with BPD, and 7 randomized controlled trials of $\alpha$-tocopherol supplementation in preterm infants were conducted for the prevention of BPD, 4 of which studied the development of BPD as the primary outcome $[70,71,73,74]$ and 3 which studied it as a secondary outcome [75-77] (Table 2). The results of these studies differ, with 1 reporting statistically significant reductions in BPD, and 6 showing nonsignificant reductions in BPD or no difference. A Cochrane meta-analysis of these same studies reported no association between vitamin $\mathrm{E}$ and $\mathrm{BPD}$ (estimated RR $0.91,95 \%$ CI 0.73 to 1.14 ; risk difference -0.02 , 95\% CI -0.07 to 0.03 ) with wide confidence intervals suggesting that studies of BPD and vitamin $\mathrm{E}$ have been underpowered, even when combined in this way [78]. What all 7 studies have in common is utilization of high-dose vitamin E supplementation rather than normalization of deficiency, lack of prestratification of participants into categories at risk for vitamin $\mathrm{E}$ deficiency, delivery of the intervention in the neonatal period rather than during pregnancy, and failure to quantify and account for an interaction effect of $\gamma$-tocopherol or its potential presence in the product being delivered [33]. Of note, all 7 provided $\alpha$-tocopherol formulated by 1 company. Of more concern, 2 of the negative studies, in particular the same 2 with reported increased side effects of necrotizing enterocolitis, utilized a preparation which included a carrier of polyoxyethylated castor oil [75, 77]. Polyoxyethylated castor oil is not biologically inert, as was believed at the time, and may cause serious adverse reactions, including direct epithelial damage [79].

Update on Vitamin E Isoforms and BPD
There is hesitancy on the part of neonatologists to reopen investigations into vitamin $\mathrm{E}$ isoforms, due to reported adverse events such as necrotizing enterocolitis, noted during the trial period in which the investigational product was being administered [77]. In undertaking this review, however, it appears that side effects may have been more likely related to the carrier vehicles $[79,80]$, to osmolality of preparations [81], or to the selection of supraphysiologic doses and target levels (Table 2). Lower concentrations of vitamin $\mathrm{E}$ are routinely included in the enteral feeds and TPN given to preterm infants without increased adverse effects, suggesting that more careful selection of vehicles and cautious dose finding trials prior to use would protect against adverse effects seen in previous trials. In addition, supportive pilot trials of specific vitamin $\mathrm{E}$ isoforms demonstrating improvements in established biomarkers for the development of BPD would be important prior to initiating large randomized controlled trials.

It is also important to acknowledge that there are some studies in opposition to the hypothesis that supplementation of $a$-tocopherol is sufficient to protect against the development of BPD. The predictive model of Falciglia et al. [61] for which preterm human infants went on to develop BPD did not demonstrate the protective effect of a-tocopherol to be independent of the effect of selenium. As selenium-deficient rats had been shown to have increased metabolism of vitamin E [82], this group speculated that vitamin $\mathrm{E}$ may be metabolized more quickly due to selenium deficiency in preterm infants under conditions of oxidative stress [61]. In another study, Berger et al. [83] administered high doses of $\alpha$-tocopherol to premature baboons exposed to prolonged hyperoxia $\left(\mathrm{FiO}_{2}\right.$ of 1.0) and, despite increasing $\alpha$-tocopherol plasma concentrations, BPD was not prevented. In one of the human trials performed by Watts et al. [73], additional supplementation of $16 \mathrm{mg}$ dl- $\alpha$-tocopherol (an amount less than what is currently contained in daily consumption of standard infant formula) starting in the first week of life in 266 infants weighing less than 1,500 g did not prevent BPD, defined at that time as continued oxygen requirement at 28 days of postnatal life. It is noteworthy that at least $40 \%$ of both the control and treatment groups in this study were receiving inspired oxygen concentrations that were much higher $\left(\mathrm{FiO}_{2}>0.8\right)$ than those typically used with close oxygen saturation targeting in neonatal intensive care units today [84]. Watts et al. [73] speculated that their study might have been underpowered for effect size, and that the lack of response could possibly be explained by the fact that predisposition for BPD may require vita- 
Table 2. Randomized controlled trials of vitamin E supplementation in premature neonates for prevention of BPD

\begin{tabular}{llllll}
\hline $\begin{array}{l}\text { Author and } \\
\text { year }\end{array}$ & Intervention studied & $\begin{array}{l}\text { Other } \\
\text { supplements }\end{array}$ & $\begin{array}{l}\text { Infants } \\
\text { analyzed, } \\
n\end{array}$ & $\begin{array}{l}\text { Group } \\
\text { allocation }\end{array}$ & Patient characteristics \\
\hline $\begin{array}{l}\text { Ehrenkranz } \\
\text { et al. }[70],\end{array}$ & $\begin{array}{l}20 \mathrm{mg} / \mathrm{kg} \text { intramuscular } \\
\text { vitamin E daily until FiO } 2 \\
\text { requirement }<0.4 \text { (vehicle } \\
\text { contained propylene glycol } \\
\text { and polysorbate } 80)\end{array}$ & None & 34 & $\begin{array}{l}18 \text { in control } \\
\text { group and } 16 \text { in } \\
\text { treatment group }\end{array}$ & $\begin{array}{l}\text { Premature infants with } \\
\text { diagnosed respiratory } \\
\text { distress syndrome who } \\
\text { survived for } 10 \text { days or } \\
\text { more (to allow } \\
\text { differentiation of } \\
\text { radiographic criteria } \\
\text { between RDS and BPD) }\end{array}$ \\
\hline
\end{tabular}

BPD studied Results
as primary or
secondary
outcome?

\begin{tabular}{|c|c|c|c|c|}
\hline $\begin{array}{l}\text { Puklin } \\
\text { et al. [109], } \\
1982\end{array}$ & $\begin{array}{l}20 \mathrm{mg} / \mathrm{kg} \text { intramuscular } \\
\text { vitamin E at study } \\
\text { admission, and } 24,48 \text {, and } \\
168 \mathrm{~h} \text { later, then twice } \\
\text { weekly until cessation of } \\
\text { oxygen requirement } \\
\text { (vehicle contained } \\
\text { propylene glycol and } \\
\text { polysorbate } 80 \text { ) }\end{array}$ & $\begin{array}{l}\text { Oral: } 50 \mathrm{IU} / \\
\text { day vitamin } \mathrm{E} \\
\text { if weight was } \\
<1,000 \mathrm{~g} \text { and } \\
25 \mathrm{IU} / \text { day if } \\
\text { weight was } \\
>1,000 \mathrm{~g} \\
\text { Given to all } \\
\text { infants }\end{array}$ & 80 & $\begin{array}{l}43 \text { in control } \\
\text { group and } 37 \text { in } \\
\text { treatment group }\end{array}$ \\
\hline
\end{tabular}

Premature infants with $\quad$ Primary
diagnosed respiratory
distress syndrome who
survived for 10 days or
more (to allow
differentiation of
radiographic criteria
between RDS and BPD)

Increase of serum vitamin $\mathrm{E}$ $\mathrm{mg}$ by the third dose administered, controls remained deficient at $0.28 \pm$ $0.06 \mathrm{mg}$. Lower incidence of moderate to severe radiographic abnormalities in the treatment group $(n=0)$ compared with the control group $(n=6)$. Infants in the treatment group demonstrated significant differences in duration of requirement for oxygen, positive pressure ventilation and endotracheal ventilation, despite statistically similar requirements during the first 5 days of life

ncrease of serum vitamin $\mathrm{E}$ from baseline $0.45 \pm 0.04$ to $5.48 \pm 0.6 \mathrm{mg}$ by the 72 -h dose, controls $0.6 \pm 0.06 \mathrm{mg}$ at $72 \mathrm{~h}$. No BPD in infants who received $<250$ h of oxygen therapy. No difference in incidence of BPD in the subset of infants who had $>250$ h of supplemental oxygen; 8 cases in controls (40\%) versus 7 in the treatment group (33\%), diagnosed by ongoing oxygen requirement at 30 days. Reanalysis of the 1978 Ehrenkranz study along with this publication reported possible diminished correlation of benefit due to the universal administration of some form of vitamin $\mathrm{E}$ to all study participants. Even controls achieved normal adult serum values due to accessory supplements

\begin{tabular}{|c|c|c|c|c|c|c|c|}
\hline $\begin{array}{l}\text { Hittner et } \\
\text { al. [75], } \\
1981\end{array}$ & $\begin{array}{l}100 \mathrm{mg} / \mathrm{kg} / \text { day oral vitamin } \\
\mathrm{E} \text { from day of life } 0 \text { to } \\
\text { discharge from the hospital } \\
\text { (reported to be } \\
\text { dl- } \alpha \text {-tocopherol) } \\
\text { (Vehicle contained } \\
\text { propylene glycol and } \\
\text { polysorbate } 80 \text { ) }\end{array}$ & None & 101 & $\begin{array}{l}51 \text { in control } \\
\text { group and } 50 \text { in } \\
\text { treatment group }\end{array}$ & $\begin{array}{l}\text { Premature infants weighing } \\
<1,500 \text { g who required } \\
\text { supplemental oxygen for } \\
\text { respiratory distress } \\
\text { syndrome } \\
\text { Excluded children who did } \\
\text { not survive for } 4 \text { weeks due } \\
\text { to need to observe retinal } \\
\text { vascularization }\end{array}$ & $\begin{array}{l}\text { Secondary } \\
\text { (primary } \\
\text { outcome } \\
\text { prevention of } \\
\text { ROP) }\end{array}$ & $\begin{array}{l}\text { No significant difference } \\
\text { between incidence of BPD in } \\
\text { controls ( } 13 \text { cases; } 26 \% \text { ) versus } \\
\text { treatment group ( } 15 \text { cases; } \\
30 \% \text { ). Severity of illness/BPD } \\
\text { diagnostic criteria not reported }\end{array}$ \\
\hline $\begin{array}{l}\text { Hittner et } \\
\text { al. [76], } \\
1984\end{array}$ & $\begin{array}{l}15 \mathrm{mg} / \mathrm{kg} \text { intramuscular } \\
\text { vitamin E given on day } 1 \\
\text { of life. } 10 \mathrm{mg} / \mathrm{kg} \\
\text { intramuscular vitamin } \mathrm{E} \\
\text { given on day } 2,4 \text {, and } 6 \\
\text { of life (reported to be } \\
\text { dl- } \alpha \text {-tocopherol) } \\
\text { (Vehicle contained } \\
\text { propylene glycol } \\
\text { polysorbate } 80 \text {, and } \\
\text { polyoxyethylated castor oil) }\end{array}$ & $\begin{array}{l}100 \mathrm{mg} / \mathrm{kg} / \mathrm{day} \\
\text { oral vitamin } \mathrm{E} \\
\text { given to all } \\
\text { infants } \\
\text { (control and } \\
\text { treatment) } \\
\text { daily until } \\
\text { retinal } \\
\text { vascularization } \\
\text { was complete }\end{array}$ & 168 & $\begin{array}{l}89 \text { in control } \\
\text { group and } 79 \text { in } \\
\text { treatment group }\end{array}$ & $\begin{array}{l}\text { Premature infants weighing } \\
<1,500 \text { g who required } \\
\text { supplemental oxygen for } \\
\text { respiratory distress } \\
\text { syndrome } \\
\text { Excluded children who did } \\
\text { not survive for } 4 \text { weeks due } \\
\text { to need to observe retinal } \\
\text { vascularization }\end{array}$ & $\begin{array}{l}\text { Secondary } \\
\text { (primary } \\
\text { outcome } \\
\text { prevention of } \\
\text { ROP) }\end{array}$ & $\begin{array}{l}\text { No significant difference } \\
\text { between incidence of BPD in } \\
\text { controls ( } 17 \text { cases; } 25.4 \% \text { ) } \\
\text { versus treatment group ( } 17 \\
\text { cases; } 25 \% \text { ). Severity of illness/ } \\
\text { BPD diagnostic criteria not } \\
\text { reported }\end{array}$ \\
\hline
\end{tabular}


Table 2 (continued)

\begin{tabular}{|c|c|c|c|c|c|c|c|}
\hline $\begin{array}{l}\text { Author and } \\
\text { year }\end{array}$ & Intervention studied & $\begin{array}{l}\text { Other } \\
\text { supplements }\end{array}$ & $\begin{array}{l}\text { Infants } \\
\text { analyzed, } \\
n\end{array}$ & $\begin{array}{l}\text { Group } \\
\text { allocation }\end{array}$ & Patient characteristics & $\begin{array}{l}\text { BPD studied } \\
\text { as primary or } \\
\text { secondary } \\
\text { outcome? }\end{array}$ & Results \\
\hline $\begin{array}{l}\text { Johnson } \\
\text { et al. [77], } \\
1989\end{array}$ & $\begin{array}{l}15 \mathrm{mg} / \mathrm{kg} \text { dl- } \alpha \text {-tocopherol } \\
\text { vitamin E given by IV with } \\
\text { a lipid emulsion, PO, or } \\
\text { intramuscular route, } \\
\text { depending on the infant's } \\
\text { feeding status } \\
\text { Dose titrated subsequently } \\
\text { to keep serum concen- } \\
\text { trations close to } 5 \mathrm{mg} / \mathrm{dL} \\
\text { in treatment group } \\
\text { (Vehicle polyoxyethylated } \\
\text { castor oil) }\end{array}$ & None & 754 & $\begin{array}{l}384 \text { in control } \\
\text { group and } 370 \text { in } \\
\text { treatment group }\end{array}$ & $\begin{array}{l}\text { Premature infants at } \\
\text { gestational age }<36 \text { weeks } \\
\text { and weighing }<2,000 \mathrm{~g}, \\
\text { matched on birth weight }\end{array}$ & $\begin{array}{l}\text { Secondary } \\
\text { (primary } \\
\text { outcome } \\
\text { prevention of } \\
\text { ROP) }\end{array}$ & $\begin{array}{l}\text { No significant difference in } \\
\text { duration of oxygen therapy or } \\
\text { duration of ventilation } \\
\text { requirements during } \\
\text { hospitalization. No official } \\
\text { diagnosis of BPD given. } \\
\text { Reported increased incidence } \\
\text { of necrotizing enterocolitis in } \\
\text { infants }<1,500 \text { g in the vitamin } \\
\text { E group after } 8 \text { days of } \\
\text { treatment (few of whom were } \\
\text { receiving enteral treatment) }\end{array}$ \\
\hline $\begin{array}{l}\text { Watts et al. } \\
{[74], 1981}\end{array}$ & $\begin{array}{l}\text { Oral vitamin E supplement } \\
\text { containing } 16 \mathrm{mg} \\
\text { dl- } \alpha \text {-tocopherol given daily } \\
\text { for } 6 \text { weeks } \\
\text { (Vehicle contained } \\
\text { propylene glycol and } \\
\text { polysorbate } 80 \text { ) }\end{array}$ & None & 138 & $\begin{array}{l}71 \text { in control } \\
\text { group and } 67 \text { in } \\
\text { treatment group }\end{array}$ & $\begin{array}{l}\text { Premature infants weighing } \\
<1,500 \text { g expected to survive } \\
48 \mathrm{~h}\end{array}$ & Primary & $\begin{array}{l}\text { No significant difference } \\
\text { between incidence of BPD in } \\
\text { controls ( } 17 \text { cases; } 24 \% \text { ) versus } \\
\text { treatment group ( } 15 \text { cases; } \\
22 \%) \text {. BPD only occurred in } \\
\text { mechanically ventilated infants }\end{array}$ \\
\hline $\begin{array}{l}\text { Watts et al. } \\
\text { [73], } 1991\end{array}$ & $\begin{array}{l}\text { Oral vitamin E supplement } \\
\text { containing } 16 \mathrm{mg} \\
\text { dl- } \alpha \text {-tocopherol given daily } \\
\text { for } 6 \text { weeks } \\
\text { (Vehicle contained } \\
\text { polysorbate } 80 \text { ) }\end{array}$ & None & 266 & $\begin{array}{l}134 \text { in control } \\
\text { group and } 132 \text { in } \\
\text { treatment group }\end{array}$ & $\begin{array}{l}\text { Premature infants weighing } \\
<1,500 \text { g expected to survive } \\
48 \mathrm{~h}\end{array}$ & Primary & $\begin{array}{l}20 \% \text { reduction in cases of BPD } \\
\text { with early death from } 23 \text { to } \\
18 \% \text { that was not statistically } \\
\text { significant given power of the } \\
\text { study. Incidence of BPD in } \\
\text { controls ( } 27 \text { cases; } 20 \%) \\
\text { compared to treatment group } \\
\text { ( } 22 \text { cases; } 17 \%) \text {. No increase in } \\
\text { necrotizing enterocolitis } \\
\text { observed with oral preparation }\end{array}$ \\
\hline
\end{tabular}

min E deficiency to be both severe and chronic (i.e., present in utero), with exposure therefore dependent on maternal status (and not infant status) at birth. Another possible explanation for some of the contradictory studies is that beyond a certain concentration of hyperoxia, antioxidant defenses, no matter how replete, may simply be inadequate to compensate for the damage caused by high fractions of inspired oxygen, free radical generation and inflammation. A third explanation is that the current definition of BPD could encompass some phenotypes which are mechanistically connected to oxidative stress, and others which are not [3]. Demonstrating a protective dose response or threshold effect of $\alpha$-tocopherol based on delivered inspired oxygen concentrations may be helpful in delineating this relationship.

\section{Future Research Directions}

Fifty years after the original description of BPD, it remains a major complication of premature birth $[85,86]$. However, not all extremely premature infants develop $\mathrm{BPD}$, suggesting that $\mathrm{BPD}$ can be prevented, if premature birth cannot. The original hypotheses driving studies of vitamin $\mathrm{E}$ on BPD are worth revisiting, even in the presence of conflicting and negative trials. Previous trials conducted utilizing lower dose oral supplements of vitamin E were underpowered $[73,74]$, and studies utilizing parenteral dosing remain in the shadow of adverse outcomes related to supraphysiologic doses with a possibly toxic vehicle [75-77]. Lastly, none of the trials targeted prenatal supplementation, as all were delivered postnatally.

As vitamin $\mathrm{E}$ is a required vitamin, and deficiency is associated with increased BPD risk, a definitive understanding of the role vitamin $\mathrm{E}$ isoforms play in BPD development is needed to inform potential prevention efforts. Table 3 outlines what we know about vitamin $\mathrm{E}$ and BPD, and important remaining gaps in our knowledge. Observational studies could identify infants and mothers at risk of vitamin E deficiency and BPD, such as those born to mothers who smoke [87], and could determine the optimal concentration ranges of each isoform to minimize BPD risk in premature neonates. Proof of concept studies could reveal the optimal timing of vitamin $\mathrm{E}$ isoform delivery on biomarkers of $\mathrm{BPD}$ 
Table 3. Use of vitamin E isoforms in therapy or prevention of BPD: review of what is known and key questions that need to be answered

\begin{tabular}{|c|c|c|}
\hline $\begin{array}{l}\text { What is known } \\
\text { There is an association between decreased } \\
\text { tocopherols and increased BPD [59-61, 64, } \\
69] \\
\text { Trials have shown mixed results, but may } \\
\text { have been affected by vehicle, route, and dose } \\
{[69,72,74-76,127]} \\
\text { What is not known } \\
\text { Are there subpopulations of infants/mothers } \\
\text { at greater risk of vitamin E deficiency and } \\
\text { PBD? (e.g., smokers) } \\
\text { Is there an optimal a- and } \gamma \text {-tocopherol range } \\
\text { associated with the lowest risk of BPD in } \\
\text { premature neonates? }\end{array}$ & $\begin{array}{l}\text { What is known } \\
\text { a- and } \gamma \text {-tocopherol have differing } \\
\text { associations with childhood respiratory } \\
\text { outcomes [53,105-107] } \\
\text { What is not known } \\
\text { Does supplementation with a specific isoform } \\
\text { of tocopherol during pregnancy or after } \\
\text { premature birth protect against PBD } \\
\text { development? } \\
\text { What are the dietary cofactors (vitamin C, } \\
\text { selenium)? } \\
\text { What is the optimal route of delivery? Enteral } \\
\text { versus TPN? } \\
\text { When is the optimal timing of intervention? } \\
\text { At-risk pregnancy or after premature birth? }\end{array}$ & $\begin{array}{l}\text { What is known } \\
\alpha \text {-and } \gamma \text {-tocopherol have differing } \\
\text { effects on lung growth and lung } \\
\text { inflammation (Table 1) } \\
\text { What is not known } \\
\text { How does supplementation with } \\
\text { specific isoforms of tocopherol alter } \\
\text { lung growth? } \\
\text { How does supplementation with } \\
\text { a- and } \gamma \text {-tocopherol alter oxygen- } \\
\text { induced lung inflammation in } \\
\text { premature infants or in models of } \\
\text { prematurity? }\end{array}$ \\
\hline
\end{tabular}

risk, and demonstrate potential mechanisms of action of individual isoforms. Mechanistic studies could help to elucidate how individual vitamin E isoforms affect lung growth and lung inflammation. Any future tocopherolbased intervention will have to account for and quantify the content of individual isoforms. In particular, we feel that renewed study of the $a$-tocopherol isoform should be considered given its protective association with the development of respiratory health outcomes such as asthma, allergic airway inflammation, and with improved lung growth parameters, compared with $\gamma$-tocopherol $[33,57,88]$.

As part of this strategy, properly conducted epidemiology studies to identify subgroups of mothers and infants at greater risk of vitamin E deficiency should take higher initial priority. In addition to vitamin $\mathrm{E}$, vitamin $\mathrm{C}$ and selenium are also known to be important in the interdependent human antioxidant system $[32,82]$. Infants of mothers who smoke have already been shown to gain significant increases in lung function and decreased likelihood of wheezing in a randomized controlled trial of supplementation of another antioxidant micronutrient, vitamin C, during pregnancy $[89,90]$. The status of vitamin E isoforms, vitamin $C$, and selenium should be examined in the maternal, infant and cord blood of smoking mothers who deliver preterm, in order to determine their association with risk of subsequent BPD.

Proof of concept studies will also be of great value moving forward. Determining the optimal timing and delivery of a tocopherol intervention will be especially important. Maternal supplementation may only lead to in- creased transmission of tocopherol metabolites [66], as only very specific isomers of $\alpha$-tocopherol cross the placenta $[91,92]$. This does not necessarily mean that the antioxidant activity is diminished, as the primary transmissible metabolite ( $\alpha$-carboxyethyl hydroxychroman) has also been shown to have good in vitro antioxidant activity [93], but with limited evidence of in vivo antioxidant activity [94]. Prenatal supplementation favoring very specific placentally transmissible isomers of $\alpha$-tocopherol, such as naturally derived RRR- $\alpha$-tocopherol $[91,92]$, in a supplement with a high overall $\alpha$-tocopherol to $\gamma$-tocopherol ratio may yield the best strategy for influencing postnatal lung outcomes. For infants at risk in the postnatal environment, the administration of tocopherol interventions may need to occur immediately after birth to prevent, rather than treat, lung damage leading to BPD. Because the intravenous route of administration of vitamin $\mathrm{E}$ in very low birth weight infants may carry an increased risk of sepsis and other adverse outcomes, and because poor vehicle selection may have contributed to toxicity in the past, we think that future intervention trials should focus on the enteral route or on modification of existing TPN formulas, and be appropriately cautious with the target dose [78].

\section{Conclusions}

At present, there is insufficient evidence about the benefits and risks of vitamin $\mathrm{E}$ in BPD prevention to make evidence-based recommendations about supplementa- 
tion. However, new data on the effects of the individual vitamin $\mathrm{E}$ isoforms on lung health should make us relook at this essential dietary factor as a potential preventive or treatment intervention for BPD. Adequately powered studies will be needed to address whether supplementation of specific vitamin $\mathrm{E}$ isoforms either in pregnant women at risk of preterm birth, or in at-risk premature infants immediately following birth, reduces the development of BPD and subsequent long-term pulmonary morbidity in childhood and adult life.

\section{Disclosure Statement}

The authors have no financial relationships or conflicts of interest relevant to this article to disclose.

\section{Funding Sources}

NIH/NHLBI T32 HL87738 (C.A.S.), UG3OD023288, HL105447, and HL129060 (C.T.M.), UG3OD023320 (J.L.A.), U01HL101456 (J.L.A., P.E.M., T.V.H.), NIH K24 AI 077930, 7 UG3 OD023282 (T.V.H.).

\section{Author Contributions}

Dr. Stone and Dr. Hartert: conceived of the topic for review, conducted literature searches and research, wrote the paper, and have primary responsibility for the final content.

Dr. McEvoy, Dr. Aschner, and Dr. Walsh: conducted literature searches and research, edited the report and contributed to the neonatology content.

Ms. Kirk: conducted literature searches and research.

Dr. Rosas-Salazar and Dr. Moore: conducted literature searches and research, and contributed to the pulmonology content.

Dr. Cook-Mills: conducted literature searches and research, and contributed to the nutrition content.

All authors read and approved the final manuscript.

\section{References}

1 Aschner J, Patrick S, Stark A, Lee S: The Scope and Organization of Neonatology: North American and Global Comparisons; in MacDonald MG, Seshia MMK (eds): Avery's Neonatology: Pathophysiology and Management of the Newborn, ed 7. Philadelphia, LWW, 2015.

2 Perrone S, Tataranno M, Buonocore G: Oxidative stress and bronchopulmonary dysplasia. J Clin Neonatol 2012;1:109-114.

3 McEvoy C, Jain L, Schmidt B, Abman S, Bancalari E, Aschner J: Bronchopulmonary dysplasia: NHLBI Workshop on the Primary Prevention of Chronic Lung Diseases. Ann Am Thorac Soc 2014;11:S146-S153.

4 Pryhuber G, Maitre N, Ballard R, Cifelli D, Davis S, Ellenberg J, Greenberg J, Kemp J, Mariani T, Panitch H, Ren C, Shaw P, Taussig L, Hamvas A: Prematurity and respiratory outcomes program (PROP): study protocol of a prospective multicenter study of respiratory outcomes of preterm infants in the United States. BMC Pediatr 2015; 15:37.

5 Higgins R, Jobe A, Koso-Thomas M, Bancalari E, Viscardi R, Hartert T, Ryan R, Kallapur S, Steinhorn R, Konduri G, Davis S, Thebaud B, Clyman R, Collaco J, Martin C, Woods J, Finer N, Raju T: Executive summary of the workshop on bronchopulmonary dysplasia. J Pediatr 2018, in press.

6 Bancalari E, del Moral T: Bronchopulmonary dysplasia and surfactant. Biol Neonate 2001; 80:7-13.

7 Campbell K: Intensive oxygen therapy as a possible cause of retrolental fibroplasia; a clinical approach. Med J Aust 1951;2:48-50.
8 Carlo W, Finer N, Walsh M, Rich W, Gantz M, Laptook A, Yoder B, Faix R, Das A, Poole W, Schibler K, Newman N, Ambalavanan N, Frantz I, Piazza A, Sánchez P, Morris B, Laroia N, Phelps D, Poindexter B, Cotten C, van Meurs K, Duara S, Narendran V, Sood B, O'Shea T, Bell E, Ehrenkranz R, Watterberg $\mathrm{K}$, Higgins R: Target ranges of oxygen saturation in extremely preterm infants. N Engl J Med 2010;362:1959-1969.

9 Stevens T, Blennow M, Myers E, Soll R: Early surfactant administration with brief ventilation vs. selective surfactant and continued mechanical ventilation for preterm infants with or at risk for respiratory distress syndrome. Cochrane Database Syst Rev 2007; 4:CD14003063

10 Wheeler $\mathrm{K}$, Klingenberg C, McCallion N, Morley C, Davis P: Volume-targeted versus pressure-limited ventilation in the neonate. Cochrane Database Syst Rev 2010;11: CD14003666.

11 Shalish W, Sant'Anna G, Natarajan G, Sanjay C: When and how to extubate premature infants from mechanical ventilation. Curr Pediatr Rep 2014;2:18-25.

12 Auten R, Davis J: Oxygen toxicity and reactive oxygen species: the devil is in the details. Nature 2009;66:121-127.

13 Guy L, Lanman J, Dancis J: The possibility of total elimination of retrolental fibroplasia by oxygen restriction. Pediatrics 1956;17:247249.

14 Welty SE: Is there a role for antioxidant therapy in bronchopulmonary dysplasia? J Nutr 2001;131:947S-950S.
15 Northway WJ, Rosan R, Porter D: Pulmonary disease following respiratory therapy of hyaline-membrane disease: bronchopulmonary dysplasia. N Engl J Med 1967;276:357-368.

16 Jobe A, Bancalari E: Bronchopulmonary dysplasia. Am J Respir Crit Care Med 2001;163: 1723-1729.

17 Rojas M, Gonzalez A, Bancalari E, Claure N, Poole C, Silva-Neto G: Changing trends in the epidemiology and pathogenesis of neonatal chronic lung disease. J Pediatr 1995;126:605610 .

18 Balinotti J, Tiller C, Llapur C, Jones M, Kimmel R, Coates C, Katz B, Nguyen J, Tepper R: Growth of the lung parenchyma early in life. Am J Respir Crit Care Med 2009;179:134137

19 Jobe A: The new bronchopulmonary dysplasia. Curr Opin Pediatr 2011;23:167-172.

20 Betteridge D: What is oxidative stress? Metabolism 2000;49:3-8.

21 Papa S, Skulachev V: Reactive oxygen species, mitochondria, apoptosis and aging. Mol Cell Biochem 1997;174:305-319.

22 Lambeth J: Nox enzymes, ROS, and chronic disease: an example of antagonistic pleiotropy. Free Radic Biol Med 2007;43:332-347.

23 Fleury CH, Mignote B, Vayssiere J: Mitochondrial reactive oxygen species in cell death signaling. Biochemie 2002;84:131-141.

24 van der Vliet A: NADPH oxidases in lung biology and pathology: host defense enzymes and more. Free Radic Biol Med 2008;44:938955 
25 Gerber C, Bruchelk G, Stegmann H, Schweinsberg F, CP S: Presence of bleomycin-detectable free iron in the alveolar system of preterm infants. Biochem Biophys Res Commun 1999; 257:218-222.

26 Nycyk J, Drury J, Cooke R: Breath pentane as a marker for lipid peroxidation and adverse outcomes in preterm infants. Arch Dis Child Fetal Neonatal Ed 1998;79:F67-F69.

27 Ogihara T, Hirano K, Morinobu T, Kim H, Hiroi M, Ogihara H, Tamai H: Raised concentration of aldehyde lipid peroxidation products in premature infants with chronic lung disease. Arch Dis Child Fetal Neonatal Ed 1999;80:F21-F25.

28 Ogihara T, Okamoto R, Kim H, Nagai A, Morinobu T, Moji H, Kamegai H, Hirano K, Ogihara H, Tamai H, Mino M: New evidence for the involvement of oxygen radicals in triggering neonatal chronic lung disease. Pediatr Res 1996;39:117-119.

29 Han R, Stewart D: Defective lung vascular development in endothelial nitric oxide synthase deficient mice. Trends Cardiovasc Med 2006;16:29-34.

30 Afshar S, Gibson L, Yuhanna I, Sherman T, Kerecman J, Grubb P, Yoder B, McCurnin D, Shaul P: Pulmonary NO synthase expression is attenuated in a fetal baboon model of chronic lung disease. Am J Physiol Lung Cell Mol Physiol 2003;284:L749-L758.

31 Miller D, Turner S, Spiteri-Cornish D, Scaife A, Danielian P, Devereux G, Walsh G: Maternal vitamin $\mathrm{D}$ and $\mathrm{E}$ intakes during early pregnancy are associated with airway epithelial cell responses in neonates. Clin Exp Allergy 2015;45:920-927.

32 Institute of Medicine: Dietary Reference Intakes for Vitamin C, Vitamin E, Selenium, and Carotenoids. Washington, National Academies Press, 2000, pp 186-283.

33 Cook-Mills JM, Abdala-Valencia H, Hartert $\mathrm{T}$ : Two faces of vitamin $\mathrm{E}$ in the lung. Am J Respir Crit Care Med 2013;188:279-284.

34 Jiang Q, Christen S, Shigenaga M, Ames B: Gamma-tocopherol, the major form of vita$\min \mathrm{E}$ in the US, deserves more attention. Am J Clin Nutr 2001;74:714-722.

35 Jiang Q: Natural forms of vitamin E: metabolism, antioxidant, and anti-inflammatory activities and their role in disease prevention and therapy. Free Radic Biol Med 2014;72: 76-90.

36 Sontag T, Parker R: Cytochrome P450 $\omega$-hydroxylase pathway of tocopherol catabolism. Biol Chem 2002;277:25290-25296.

37 Leonard S, Patterson E, Atkinson J, Ramakrishnan R, Cross C, Traber M: Studies in humans using deuterium-labeled alpha- and gamma-tocopherols demonstrate faster plasma gamma-tocopherol disappearance and greater gamma-metabolite production. Free Radic Biol Med 2005;38:856-866.

38 Herrera E, Barbas C: Vitamin E: action, metabolism and perspectives. J Physiol Biochem 2001;57:43-56.
39 Horwitt M, Harvey C, Dahm C Jr, Searcy M: Relationship between tocopherol and serum lipid levels for determination of nutritional adequacy. Ann NY Acad Sci 1972;203:223236.

40 Rochow N, Moller S, Fusch G, Drogies T, Fusch C: Levels of lipids in preterm infants fed breast milk. Clin Nutr 2010;29:94-99.

41 Thurnham D, Davies J, Crump B, Situnayake $\mathrm{R}$, Davis M: The use of different lipids to express serum tocopherol: lipid ratios for the measurement of vitamin E status. Ann Clin Biochem 1986;23:514-520.

42 Reiter E, Jiang Q, Christen S: Anti-inflammatory properties of $\alpha$ - and $\gamma$-tocopherol. Mol Aspects Med 2007;28:668-691.

43 Burbank A, Duran C, Almond M, Wells H, Jenkins S, Jiang Q, Yang C, Wang T, Zhou H, Hernandez M, Peden D: A short course of gamma-tocopherol mitigates LPS-induced inflammatory responses in humans ex vivo. J Allergy Clin Immunol 2017;140:1179-1181.

44 Burbank A, Duran C, Pan Y, Burns P, Jones S, Jiang Q, Yang C, Jenkins S, Wells H, Alexis N, Kesimer M, Bennett W, Zhou H, Peden D, Hernandez M: Gamma tocopherol-enriched supplement reduces sputum eosinophilia and endotoxin-induced sputum neutrophilia in volunteers with asthma. J Allergy Clin Immunol 2017, Epub ahead of print.

45 Eldridge M, Peden D: Allergen provocation augments endotoxin-induced nasal inflammation in subjects with atopic asthma. J Allergy Clin Immunol 2000;105:475-481.

46 Hernandez M, Wagner J, Kala A, Mills K, Wells $\mathrm{H}$, Alexis N, Lay J, Jiang Q, Zhang H, Zhou H, Peden D: Vitamin E, $\gamma$-tocopherol, reduces airway neutrophil recruitment after inhaled endotoxin challenge in rats and in healthy volunteers. Free Radic Biol Med 2013; 60:56-62.

47 Mills K, Lay J, Wu W, Robinette C, Kesic M, Dreskin S, Peden D, Hernandez M: Vitamin E, $\gamma$-tocopherol, diminishes ex vivo basophil response to dust mite allergen. Allergy 2014; 69:541-544.

48 Wagner J, Harkema J, Jiang Q, Illek B, Ames B, Peden D: $\gamma$-Tocopherol attenuates ozoneinduced exacerbation of allergic rhinosinusitis in rats. Toxicol Pathol 2009;37:481-491.

49 Wagner J, Jiang Q, Harkema J, Ames B, Illek B, Roubey R, Peden D: $\gamma$-Tocopherol prevents airway eosinophilia and mucous cell hyperplasia in experimentally induced allergic rhinitis and asthma. Clin Exp Allergy 2008;38: 501-511.

50 Wagner J, Jiang Q, Harkema J, Illek B, Patel D, Ames B, Peden D: Ozone enhancement of lower airway allergic inflammation is prevented by $\gamma$-tocopherol. Free Radic Biol Med 2007;43:1176-1188.

51 Wiser J, Alexis N, Jiang Q, Wu W, Robinette C, Roubey R, Peden D: In vivo $\gamma$-tocopherol supplementation decreases systemic oxidative stress and cytokine responses of human monocytes in normal and asthmatic subjects. Free Radic Biol Med 2008;45:40-49.
52 Berdnikovs S, Abdala-Valencia H, McCary C, Somand M, Cole R, Garcia A, Bryce P, CookMills J: Isoforms of vitamin $\mathrm{E}$ have opposing immunoregulatory functions during inflammation by regulating leukocyte recruitment. J Immunol 2009;182:4395-4405.

53 McCary C, Abdala-Valencia H, Berdnikovs S, Cook-Mills JM: Supplemental and highly elevated tocopherol doses differentially regulate allergic inflammation: reversibility of $\alpha$-tocopherol and $\gamma$-tocopherol's effects. J Immunol 2011;186:3674-3685.

54 Marchese M, Kumar R, Colangelo L, Avila P, Jacobs D, Gross M, Sood A, Liu K, Cook-Mills $\mathrm{J}$ : The vitamin $\mathrm{E}$ isoforms $\alpha$-tocopherol and $\gamma$-tocopherol have opposite associations with spirometric parameters: the CARDIA study. Respir Res 2014;15:31.

55 Yoshikawa S, Morinobu T, Hamamura K, Hirahara F, Iwamoto T, Tamai $\mathrm{H}$ : The effect of $\gamma$-tocopherol administration on $\alpha$-tocopherol levels and metabolism in humans. Eur J Clin Nutr 2005;59:900-905.

56 Larkin E, Gao Y, Gebretsadik T, Hartman T, Wu P, Wen W, Yang G, Bai C, Jin M, Roberts L, Gross M, Shu X, Hartert T: New risk factors for adult-onset incident asthma: a nested case-control study of host antioxidant defense. Am J Respir Crit Care Med 2015;191: 45-53.

57 Turner SW, Campbell D, Smith N, Craig LCA, McNeill G, Forbes SH, Harbour PJ, Seaton A, Helms PJ, Devereux GS: Associations between fetal size, maternal $\alpha$-tocopherol and childhood asthma. Thorax 2010;65:391397.

58 Islam S, Narra V, Cote GM, Manganaro TF, Donahoe PK, Schnitzer JJ: Prenatal vitamin E treatment improves lung growth in fetal rats with congenital diaphragmatic hernia. J Pediatr Surg 1999;34:172-176.

59 Peroni DG, Bonomo B, Casarotto S, Boner AL Piacentini GL: How changes in nutrition have influenced the development of allergic diseases in childhood. Ital J Pediatr 2012;38:22.

60 Falciglia HS, Johnson JR, Sullivan J, Hall CF, Miller JD: Complex antioxidant relationships and derangements in premature infants with respiratory-distress syndrome and bronchopulmonary dysplasia. Pediatr Res 1994;35: A51-A51.

61 Falciglia HS, Johnson JR, Sullivan JA, Hall CF, Miller JD, Riechmann GC, Falciglia GA: Role of antioxidant nutrients and lipid peroxidation in premature infants with respiratory distress syndrome and bronchopulmonary dysplasia. Am J Perinatol 2003;20:97-107.

62 Falciglia H, Ginn-Pease M, Falciglia G, Lubin A, Frank D, Chang W: Vitamin E and selenium levels of premature infants with severe respiratory distress syndrome and bronchopulmonary dysplasia. J Pediatr Perinat Nutr 1988;2:35-49.

63 Haga P, Ek J, Kran S: Plasma tocopherol levels and vitamin $\mathrm{E} / \beta$-lipoprotein relationships during pregnancy and in cord blood. Am J Clin Nutr 1982;36:1200-1204. 
64 Hoppu U, Salo-Vaananen P, Lampi A-M, Isolauri E: Serum alpha- and gamma-tocopherol levels in atopic mothers and their infants are correlated. Biol Neonate 2005;88:24-26.

$65 \mathrm{Wu}$ S, Chou Y: Measurement of serum vitamin $\mathrm{E}$ isomers in fullterm and preterm infants. Chang Gung Med J 2001;24:793-798.

66 Didenco S, Gillingham M, Go M, Leonard S, Traber M, McEvoy C: Increased vitamin E intake is associated with higher $\alpha$-tocopherol concentration in the maternal circulation but higher a-carboxyethyl hydroxychroman concentration in the fetal circulation. Am J Clin Nutr 2011;93:368-373.

67 Romeu-Nadal M, Morera-Pons S, Castellote AI, Lopez-Sabater MC: Determination of $\gamma$ and $\alpha$-tocopherols in human milk by a direct high-performance liquid chromatographic method with UV-vis detection and comparison with evaporative light scattering detection. J Chromatogr A 2006;1114:132-137.

68 Lima M, Dimenstein R, Ribeiro K: Vitamin E concentration in human milk and associated factors: a literature review. J Pediatr 2014;90: 440-448.

69 Elisia I, Kitts D: Differences in vitamin E and $\mathrm{C}$ profile between infant formula and human milk and relative susceptibility to lipid oxidation. Int J Vitam Nutr Res 2013;83:311-319.

70 Ehrenkranz R, Bonta B, RC A, Warshaw J: Amelioration of bronchopulmonary dysplasia after vitamin E administration - a preliminary report. N Engl J Med 1978;299:564-569.

71 Ehrenkranz RA, Ablow R, Warshaw J: Prevention of bronchopulmonary dysplasia with vitamin $\mathrm{E}$ administration during the acute stages of respiratory distress syndrome. J Pediatr 1979;95:873-878.

72 Behrman R, Saldanha RL, Cepeda EE, Poland RL: The effect of vitamin E prophylaxis on the incidence and severity of bronchopulmonary dysplasia. J Pediatr 1982;101:89-93.

73 Watts JL, Milner R, Zipursky A, Paes B, Ling E, Gill G, Fletcher B, Rand C: Failure of supplementation with vitamin-E to prevent bronchopulmonary dysplasia in infants less than 1,500 g birth weight. Eur Respir J 1991; $4: 188-190$.

74 Milner R, Watts J, Paes B, Zipursky A: RLF in $<1,500$ Gram Neonates. Part of a Randomized Clinical Trial of the Effectiveness of Vitamin E: Retinopathy of Prematurity Conference. Columbus, Ross Laboratories, 1981, pp 703 716

75 Hittner H, Godio L, Rudolph A, Adams J, Garcia-Prats J, Friedman Z, Kautz J, Monaco $\mathrm{W}$ : Retrolental fibroplasia: efficacy of vitamin $\mathrm{E}$ in a double-blind clinical study of preterm infants. N Engl J Med 1981;305:1365-1371.

76 Speer M, Bilfeld C, Rudolph A, Chadda P, Holbein M, Hittner H: Intraventricular hemorrhage and vitamin $\mathrm{E}$ in the very low-birthweight infant: evidence for efficacy of early intramuscular vitamin $\mathrm{E}$ administration. $\mathrm{Pe}$ diatrics 1984;74:1107-1112.
77 Johnson L, Quinn G, Abbasi S, Otis C, Goldstein D, Sacks L, Porat R, Fong E, DelivoriaPapadopoulos M, Peckham G, Schaffer D, Bowen JF: Effect of sustained pharmacologic vitamin $E$ levels on incidence and severity of retinopathy of prematurity: a controlled clinical trial. J Pediatr 1989;114:827-838.

78 Brion L, Bell E, Raghuveer T: Vitamin E supplementation for prevention of morbidity and mortality in preterm infants. Cochrane Database Syst Rev 2003;4:CD003665.

79 Kiss L, Walter F, Bocsik A, Veszelka S, Ozsvari B, Puskas L, Szabo-Revesz P, Deli M: Kinetic analysis of the toxicity of pharmaceutical excipients cremophor EL and RH40 on endothelial and epithelial cells. J Pharm Sci 2013; 102:1173-1181.

80 Campos F, Victorino V, Martins-Pinge M, Cecchini A, Panis C, Cecchini R: Systemic toxicity induced by paclitaxel in vivo is associated with the solvent cremophor EL through oxidative stress-driven mechanisms. Food Chem Toxicol 2014;68:78-86.

81 Finer N, Peters K, Hayek Z, Merkel C: Vitamin $\mathrm{E}$ and necrotizing enterocolitis. Pediatrics 1984;73:387-393.

82 Fischer WC, Whanger PD: Effects of selenium deficiency on vitamin-E metabolism in rats. J Nutr Sci Vitaminol 1977;23:273-280.

83 Berger TM, Frei B, Rifai N, Avery ME, Suh J, Yoder BA, Coalson JJ: Early high dose antioxidant vitamins do not prevent bronchopulmonary dysplasia in premature baboons exposed to prolonged hyperoxia: a pilot study. Pediatr Res 1998;43:719-726.

84 Vento M, Moro M, Escrig M, Arruza L, Villar G, Izquierdo I, Roberts L, Arduini A, Escobar J, Sastre J, Asensi M: Preterm resuscitation with low oxygen causes less oxidative stress, inflammation and chronic lung disease. Pediatrics 2009;124:e439-e449.

85 Johnson T, Patel A, Jegier B, Engstrom J, Meier $\mathrm{P}$ : The cost of morbidities in very low birth weight infants. J Pediatr 2013;162:243-249. e241.

86 Miller V, Rice J, DeVoe M, Fos P: An analysis of program and family costs of case managed care for technology-dependent infants with bronchopulmonary dysplasia. J Pediatr Nurs 1998; 13:244-251.

87 Stone C Jr, Qiu Y, Kurland I, Slaughter J, Moore P, Cook-Mills J, Hartert T, Aschner J: Effect of maternal smoking on plasma and urinary measures of vitamin $\mathrm{E}$ isoforms in the first month after extreme preterm birth. J Pediatr 2018, Epub ahead of print.

88 Cook-Mills J, Gebretsadik T, Abdala-Valencia H, Green J, Larkin E, Dupont W, Shu X, Gross M, Bai C, Gao Y, Hartman T, RosasSalazar C, Hartert T: Interaction of vitamin E isoforms on asthma and allergic airway disease. Thorax 2016;71:954-956.
89 McEvoy C, Schilling D, Clay N, Jackson K, Go M, Spitale P, Bunten C, Leiva M, Gonzales D, Hollister-Smith J, Durand M, Frei B, Buist A, Peters D, Morris C, Spindel E: Vitamin $C$ supplementation for pregnant smoking women and pulmonary function in their newborn infants: a randomized clinical trial. JAMA 2014;311:2074-2082.

90 Ortega R, López-Sobaler A, Martinez R, Andrés P, Quintas M: Influence of smoking on vitamin $\mathrm{E}$ status during the third trimester of pregnancy and on breast-concentrations in Spanish women. Am J Clin Nutr 1998;68: 662-667.

91 Acuff R, Dunworth R, Webb L, Lane J: Transport of deuterium-labeled tocopherols during pregnancy. Am J Clin Nutr 1998;67: 459-464.

92 Debier C, Larondelle Y: Vitamins A and E: metabolism, roles and transfer to offspring. Br J Nutr 2005;93:153-174.

93 Betancor-Fernandez A, Sies H, Stahl W, Polidori M: In vitro antioxidant activity of 2,5,7,8-tetramethyl-2-(2-carboxyethyl)-6hydroxychroman (alpha-CEHC), a vitamin E metabolite. Free Radic Res 2002;36:915921.

94 Uto-Kondo H, Kiyose C, Ohmori R, Saito $\mathrm{H}$, Taguchi C, Kishimoto Y, Machida N, Hasegawa M, Yoshioka E, Saita E, Hirata Y, Igarashi $\mathrm{O}$, Kondo $\mathrm{K}$ : The coantioxidative effects of carboxyethyl-6-hydroxychromans and $a$-tocopherol. J Nutri Sci Vitaminol (Tokyo) 2007;53:301-305.

95 Contin D, Munne-Bosch S: Interspecific variation in vitamin $\mathrm{E}$ levels and the extent of lipid peroxidation in pioneer and non-pioneer species used in tropical forest restoration. Tree Physiol 2016;36:1151-1161.

96 Meydani S, Barklund M, Liu S, Meydani M, Miller R, Cannon J, Morrow F, Rocklin R, Blumberg J: Vitamin E supplementation enhances cell-mediated immunity in healthy elderly subjects. Am J Clin Nutr 1990;52: 557-563.

97 Hsieh C, Huang C, Lin B: Low and high levels of $a$-tocopherol exert opposite effects on IL-2 possibly through the modulation of PPAR- $\gamma$, I $\kappa \mathrm{B} \alpha$, and apoptotic pathway in activated splenocytes. Nutrition 2006;22:433440.

98 Jiang Q, Ames B: $\gamma$-Tocopherol, but not a-tocopherol, decreases proinflammatory eicosanoids and inflammation damage in rats. FASEB J 2003;17:816-822.

99 Jiang Q, Elson-Schwab I, Courtemanche C, Ames B: Gamma tocopherol and its major metabolite, in contrast to alpha tocopherol, inhibit cyclooxygenase activity in macrophages and epithelial cells. Proc Natl Acad Sci USA 2000;97:11494-11499.

100 Wu D, Meydani M, Beharka A, Serafini M, Martin K, Meydani S: In vitro supplementation with different tocopherol homologues can affect the function of immune cells in old mice. Free Radic Biol Med 2000;28:643-651. 
101 Boscoboinik D, Chatelin E, Bartoli G, Azzi A: Molecular basis of alpha-tocopherol inhibition of smooth muscle proliferation in vitro. EXS 1992;62:164-177.

102 Kempna P, Reiter E, Arock M, Azzi A, Zingg J: Inhibition of HMC-1 mast cell proliferation by vitamin $\mathrm{E}$ : involvement of the protein kinase B pathway. J Biol Chem 2004; 279:50700-50709.

103 Gerondakis S, Siebenlist U: Roles of the NF$\kappa B$ pathway in lymphocyte development and function. Cold Spring Harb Perspect Biol 2010;2:a000182.

$104 \mathrm{Oh} \mathrm{H}$, Ghosh S: NF-kB: roles and regulation in different $\mathrm{CD} 4^{+} \mathrm{T}$-cell subsets. Immunol Rev 2013;252:41-51.

105 Devaraj S, Jialal I: Low-density lipoprotein postsecretory modification, monocyte function, and circulating adhesion molecules in type 2 diabetic patients with and without macrovascular complications: the effect of a-tocopherol supplementation. Circulation 2000;102:191-196.
106 Devaraj S, Li D, Jialal I: The effects of alpha tocopherol supplementation on monocyte function. Decreased lipid oxidation, interleukin 1 beta secretion, and monocyte adhesion to endothelium. J Clin Invest 1996;98: 756-763.

107 Abdala-Valencia H, Berdnikovs S, Soveg F, Cook-Mills J: $\alpha$-Tocopherol supplementation of allergic female mice inhibits development of $\mathrm{CD} 11 \mathrm{c}^{+} \mathrm{CD} 11 \mathrm{~b}^{+}$dendritic cells in utero and allergic inflammation in neonates. Am J Physiol Lung Cell Mol Physiol 2014; 307:L482-L496.

108 Abdala-Valencia H, Soveg F, Cook-Mills J: $\gamma$-Tocopherol supplementation of allergic female mice augments development of $\mathrm{CD} 11 \mathrm{c}^{+} \mathrm{CD} 11 \mathrm{~b}^{+}$dendritic cells in utero and allergic inflammation in neonates. Am J Physiol Lung Cell Mol Physiol 2016;310: L759-L771.

109 Puklin J, Simon R, Ehrenkranz R: Influence on retrolental fibroplasia of intramuscular vitamin $\mathrm{E}$ administration during respiratory distress syndrome. Opthalmology 1982;89: 96-103.
110 Al-Sonboli N, Al-Aghbari N, Al-Aryani A, Atef Z, Brabin B, Shenkin A, Roberts E, Harper G, Hart C, Cuevas L: Micronutrient concentrations in respiratory syncytial virus and human metapneumovirus in Yemeni children. Ann Trop Paediatr 2009;29:35-40.

111 Galabov A, Mileva M, Simeonova L, Gegova G: Combination activity of neuraminidase inhibitor oseltamivir and $\alpha$-tocopherol in influenza virus A (H3N2) infection in mice. Antivir Chem Chemother 2015;24:83-91.

112 Sheridan P, Beck M: The immune response to herpes simplex virus encephalitis in mice is modulated by dietary vitamin E. J Nutr 2008:138:130-137.

113 Sheridan P, Beck M: The dendritic and T cell responses to herpes simplex virus-1 are modulated by dietary vitamin E. Free Radic Biol Med 2009;46:1581-1588.

114 Beck M, Williams-Toone D, Levander O: Coxsackievirus B3-resistant mice become susceptible in Se/vitamin E deficiency. Free Radic Biol Med 2003;34:1263-1270. 